\title{
Dexamethasone administration attenuates the inhibitory effect of lipopolysaccharide on IGF-I and IGF-binding protein-3 in adult rats
}

\author{
Teresa Priego, Miriam Granado, Ana Isabel Martín ${ }^{1}$, \\ Asunción López-Calderón and María Angeles Villanúa \\ Department of Physiology, Faculty of Medicine, Complutense University, Avda. Complutense s/n, 28040 Madrid, Spain \\ ${ }^{1}$ Department of Morphology and Physiology, European University, 28670 Madrid, Spain \\ (Requests for offprints should be addressed to M A Villanúa; Email: anvi@med.ucm.es)
}

\begin{abstract}
The aim of this study was to investigate whether glucocorticoid administration had a beneficial effect on serum concentrations of insulin-like growth factor I (IGF-I) and on IGF-binding protein 3 (IGFBP-3) in rats injected with lipopolysaccharide (LPS). Adult male rats were injected with LPS or saline and pretreated with dexamethasone or saline. Dexamethasone administration decreased growth hormone $(\mathrm{GH})$ receptor and IGF-I mRNA levels in the liver of control rats. LPS decreased GH receptor and IGF-I gene expression in the liver of saline-treated rats but not in the liver of dexamethasone-pretreated rats. In the kidney, GH receptor mRNA levels were not modified by dexamethasone or LPS treatment. However, LPS decreased renal IGF-I gene expression and dexamethasone pretreatment prevented this decrease. Serum concentrations of IGF-I were decreased by LPS, and dexamethasone pretreatment attenuated this effect. The gene expression of
\end{abstract}

IGFBP-3 in the liver and kidney and its circulating levels were decreased by LPS. In control rats dexamethasone increased circulating IGFBP-3 and its gene expression in the liver, and decreased the proteolysis of this protein. Dexamethasone pretreatment attenuated the LPS-induced decrease in IGFBP-3 gene expression in the liver and prevented the LPS-induced decrease in IGFBP-3 gene expression in the kidney. Moreover, dexamethasone pretreatment attenuated the LPS-induced decrease in serum concentrations of IGFBP-3 and decreased the LPSinduced IGFBP-3 proteolysis in serum. In conclusion, dexamethasone pretreatment partially attenuates the inhibitory effect of LPS on serum IGF-I by blocking the decrease of its gene expression in the kidney as well as by attenuating the decrease in serum concentrations of IGFBP-3.

Journal of Endocrinology (2005) 185, 467-476

\section{Introduction}

Catabolism and growth impairment are complications of several situations such as sepsis and inflammatory diseases. These situations are associated with neuroendocrine changes that contribute to the catabolic state and that include an increase in serum concentrations of glucocorticoids together with a decrease in serum insulinlike growth factor I (IGF-I). Sepsis can be induced experimentally by administering lipopolysaccharide (LPS), a component of the wall of gram-negative bacteria. LPS administration decreases circulating levels of IGF-I both in humans (Lang et al. 1997) and in experimental animals (Fan et al. 1994, Soto et al. 1998). We have previously observed that the decrease in serum IGF-I is associated with a decrease in growth hormone $(\mathrm{GH})$ receptor and IGF-I synthesis in the liver (Priego et al. 2002a, 2003a).

IGF-I is an important mitogen and acts in an endocrine, paracrine or autocrine manner. The bioactivity of this growth factor is regulated by IGF-I binding proteins
(IGFBPs), where IGFBP-3 is the main carrier of circulating IGF-I. This binding protein can increase the half-life of circulating IGF-I and control the access of IGF-I to extravascular target tissues. IGFBP-3 also plays an important role in the cellular environment, where it may both inhibit and potentiate IGF-I-stimulated DNA synthesis (De Mellow \& Baxter 1988). The mechanisms by which IGFBP-3 activity can be regulated are through its organ synthesis or through its proteolysis. This last modulation generates fragments that bind IGF with lower affinity compared with intact IGFBP-3, resulting in an increased bioavailability of IGF (Blat et al. 1994). We have previously reported that in LPS-treated rats there was a decrease in serum concentrations of IGFBP-3 and in its synthesis in the liver (Priego et al. 2003b).

LPS administration to rats induces an activation of the hypothalamic-pituitary-adrenal axis, shown by an increase in serum adrenocorticotropin and corticosterone concentrations (Fan et al. 1994, Priego et al. 2002a). The increased levels of glucocorticoids after acute endotoxin exposure 
could be the mediator of depressed serum and liver IGF-I levels, since the glucocorticoid, dexamethasone, inhibits IGF-I synthesis in the liver (Luo \& Murphy 1989) and decreases GH receptor (Gabrielsson et al. 1995). However, we have recently reported that glucocorticoids are not responsible for the inhibitory effect of LPS on circulating IGF-I and IGFBP-3, as well as their gene expression in the liver (Priego et al. 2002a,b). Moreover, prevention of the increase in glucocorticoid secretion after LPS by adrenalectomy potentiates the inhibitory effect of LPS on serum and liver IGF-I (Priego et al. 2002a). This fact suggests that glucocorticoids have a beneficial effect, probably preventing the release of an IGF-I inhibitory factor. Nitric oxide (NO) could be one of the possible inhibitory factors. We have observed that administration of an inducible NO synthase (iNOS) inhibitor prevented the increase in serum nitrites and nitrates as well as the decrease in both IGF-I and IGFBP-3 serum levels and their hepatic mRNA levels induced by LPS (Priego et al. 2004). Furthermore, it has been reported that dexamethasone decreases hepatocyte iNOS mRNA levels in vitro (Geller et al. 1993). On the other hand, corticosteroid therapy has been considered as beneficial in the treatment of septic shock patients in recent years. Several studies have shown that corticosteroid therapy appears to aid in the treatment of the shock state and lead to a more rapid reversal of the hemodynamic alterations. As a consequence of the hemodynamic improvement, there was also a benefit to overall mortality (Annane et al. 2002, Yildiz et al. 2002).

Taking into account the fact that in the last few years glucocorticoid therapy has been considered beneficial in the treatment of septic shock patients, reducing mortality, the present study was conducted in order to analyze if dexamethasone preteatment is able to prevent the effect of LPS on the serum IGF-I-IGFBP-3 system and in this way counteract the catabolic response associated with the sepsis situation. Although the liver is the main source of serum IGF-I (Sjogren et al. 1999), the kidney has also been reported as another source ( $\mathrm{Li}$ et al. 1997, Ibáñez de Cáceres et al. 2002b). For this reason, hepatic and renal IGF-I and IGFBP-3 mRNA levels were measured. Moreover, we wanted to analyze if the effects of dexamethasone pretreatment in LPS-treated rats could be mediated by NO. For this purpose, serum concentrations of nitrite and nitrate, as an index of $\mathrm{NO}$ production, were also analyzed.

\section{Materials and Methods}

Animals and experimental design

Male Wistar rats (250 g; Charles River, Barcelona, Spain) were used for the experiment. They were housed three or four per cage with free access to food and water, under constant conditions of temperature $\left(20-22{ }^{\circ} \mathrm{C}\right)$ and light (lights on from 0730 to $1930 \mathrm{~h}$ ). The procedures followed the guidelines recommended by the European Union for the care and use of laboratory animals. Forty rats were injected intraperitoneally with LPS $(250 \mu \mathrm{g} / \mathrm{kg})$ or saline at $1800 \mathrm{~h}$ on one day and at $1000 \mathrm{~h}$ on the following day. Rats were killed by decapitation $3 \mathrm{~h}$ after the second LPS or saline injection, between $1300 \mathrm{~h}$ and $1345 \mathrm{~h}$. This LPS administration protocol has been shown to decrease levels of serum IGF-I and its mRNA in the liver (Priego et al. 2003a). In order to study if glucocorticoid administration is able to prevent the effect of LPS on IGF-I, rats were pretreated with dexamethasone. Dexamethasone (SigmaAldrich, Madrid, Spain) was injected subcutaneously $(200 \mu \mathrm{g} / \mathrm{kg})$ two hours before each LPS injection (at $1600 \mathrm{~h}$ on the first day and at $0800 \mathrm{~h}$ on the second day). Control rats were injected with saline. Trunk blood was collected in cooled tubes, allowed to clot, centrifuged and the serum stored at $-20{ }^{\circ} \mathrm{C}$ until nitrites and nitrates, IGF-I and IGFBP-3 analyses were performed. Immediately after decapitation the liver and kidney were removed, frozen in liquid nitrogen and stored at $-80{ }^{\circ} \mathrm{C}$ until RNA extraction was performed.

\section{Determination of nitrite and nitrate concentrations}

Nitrite and nitrate concentrations in serum were measured by a modified method of the Griess assay, described by Miranda et al. (2001). Serum was deproteinized to reduce turbidity by centrifugation through a $30-\mathrm{kDa}$ molecular mass filter using a Centrifree Micropartition device with a YM-30 ultrafiltration membrane (Amicon Division, Millipore Corporation, Bedford, TX, USA), at 15000 r.p.m. for $1 \mathrm{~h}$ at $37^{\circ} \mathrm{C}$ for $300 \mu \mathrm{l}$ samples. One hundred microliters filtered serum were mixed with $100 \mu \mathrm{l}$ vanadium chloride, quickly followed by the addition of the Griess reagents. The determination was performed after incubation at $37^{\circ} \mathrm{C}$ for $30 \mathrm{~min}$. The absorbance was measured at $540 \mathrm{~nm}$. Nitrite and nitrate concentrations were calculated using a $\mathrm{NaNO}_{2}$ standard curve and were expressed as $\mu \mathrm{M}$.

\section{Hormone measurements}

Serum IGF-I was removed from IGFBPs by an acidethanol extraction and was measured by a double-antibody RIA (Soto et al. 1998). The IGF-I antiserum (UB-2495) was a gift from Drs Underwood and Van Wyk, and was distributed by the Hormone Distribution Program of NIDDK (Bethesda, MD, USA) through the National Hormone and Pituitary Program. Levels of IGF-I were expressed in terms of IGF-I from Gropep (Adelaide, Australia). The sensitivity of the assay was $20 \mathrm{pg} / \mathrm{ml}$. The intra-assay coefficient of variation was $8 \%$. All samples were run in the same assay.

\section{Western ligand blot}

Western blots were prepared as previously described (Soto et al. 1998). Blood serum proteins were separated by 
$12.5 \%$ SDS-PAGE under non-reducing conditions and blotted onto nitrocellulose membranes (Hybond-C-extra; Amersham, Little Chalfont, Bucks, UK) by means of a semidry electrophoretic transfer cell (Bio-Rad, Hercules, CA, USA). The blots were dried and blocked for $1 \mathrm{~h}$ with $5 \%$ nonfat dry milk and $0 \cdot 1 \%$ Tween (Sigma) in Trisbuffered saline and incubated overnight at $4{ }^{\circ} \mathrm{C}$ with ${ }^{125}$ I-labeled IGF-I $\left(5 \times 10^{5}\right.$ c.p.m. $\left./ \mathrm{ml}\right)$. The nitrocellulose sheets were washed and dried, and blots were exposed at - $80{ }^{\circ} \mathrm{C}$ to X-ray film (Kodak X-Omat AR; Eastman Kodak, Rochester, NY, USA) and two intensifying screens for 1-3 days according to the signal obtained. The signals of the film were quantified by densitometric scanning using a Gengenius (Syngene, Cambridge, Cambs, UK). The density of the IGFBP-3 band in each lane was expressed as the percentage of the mean density of sera from control rats injected with saline.

\section{Proteolysis assay}

To measure the IGFBP-3 proteolysis in serum, we used the Lamson et al. (1991) method. Serum samples $(5 \mu \mathrm{l})$ were mixed with 15000 c.p.m. ${ }^{125}$ I-rhIGFBP-3 (glycosylated recombinant human IGFBP-3 (GroPep) iodinated using the chloramine T method) in a total volume of $30 \mu \mathrm{l}$ in $0.05 \mathrm{M}$ phosphate buffer, $\mathrm{pH} 7 \cdot 4$. The mixture was incubated for $18 \mathrm{~h}$ at $37^{\circ} \mathrm{C}$, and the reaction was stopped by adding $10 \mu \mathrm{l}$ non-reducing sample buffer and then boiling. Ten microliters of the mixture were subjected to $12.5 \%$ SDS-PAGE and run at $160 \mathrm{~mA}$ for $2 \mathrm{~h}$. Gels were fixed and dried (Bio-Rad Gel Drying System-543) and exposed to X-ray film at $-80{ }^{\circ} \mathrm{C}$ for $2-3$ days according to the signal obtained. The intact ${ }^{125}$ I-rhIGFBP-3 (42- to $45-\mathrm{kDa}$ band) from each sample was measured by densitometry. Proteolysis was expressed as the percentage of the total optical density from heat inactivated serum $\left(56^{\circ} \mathrm{C}\right.$ for $30 \mathrm{~min})$.

\section{RNA extraction and Northern blot analysis}

Total RNA extraction was performed with a kit (Ultraspec RNA; Biotecx Laboratories, Houston, TX, USA) following the manufacturer's instructions. For Northern blotting, $30 \mu \mathrm{g}$ denatured RNA from livers and kidneys were separated by formaldehyde-agarose gel electrophoresis, transferred to nylon membranes (Hybond-N+; Amersham) by overnight capillary blotting and fixed by UV crosslinking (Fotodyne, Hartland, WI, USA).

Hepatic and renal levels of IGF-I and GH receptor mRNA were measured by Northern blot hybridization using riboprobes (Roberts et al. 1987, Baumbach et al. 1989). The rat IGF-I and GH receptor probes were derived from a HindIII fragment of the pGEM-3 plasmid vector (Promega, Madison, WI, USA). ${ }^{32} \mathrm{P}$-labeled RNA antisense probes were generated from linearized plasmid with $\left[\alpha-{ }^{32}\right.$ P]CTP (Nuclear Ibérica, Madrid, Spain) and
T7 RNA polymerase (Roche Molecular Biochemicals, Barcelona, Spain).

Prehybridization was performed for $30 \mathrm{~min}$ at $68^{\circ} \mathrm{C}$ in ULTRAhyb buffer (Ambion, Austin, TX, USA) followed by hybridization for $16 \mathrm{~h}$ at the same temperature with $1 \times 10^{6}$ c.p.m./ml IGF-I-labeled riboprobe or $3 \times 10^{6}$ c.p.m./ml GH receptor-labeled riboprobe, in the same buffer. The membranes were washed twice with $2 \times$ SSC, $0 \cdot 1 \%$ SDS at $68^{\circ} \mathrm{C}$ for $10 \mathrm{~min}$, and twice with $0 \cdot 1 \times$ SSC, $0 \cdot 1 \%$ SDS at $68^{\circ} \mathrm{C}$, also for $10 \mathrm{~min}$.

The rat IGFBP-3 cDNA probe encodes the IGFBP-3 protein mRNA (Albiston \& Herington 1990). The probe was obtained by cutting the PEGEM $4 \mathrm{Z}$ plasmid vector using EcoR1 and HindIII. Prehybridization was performed for $30 \mathrm{~min}$ in ULTRAhyb buffer, followed by hybridization at $42{ }^{\circ} \mathrm{C}$ for $16 \mathrm{~h}$ with $3 \times 10^{6}$ c.p.m. $/ \mathrm{ml}$ IGFBP-3 labeled with a random priming DNA labeling kit (DECAprimeTM II; Ambion). The membranes were washed twice with $2 \times \mathrm{SSC}, 0 \cdot 1 \%$ SDS at $42{ }^{\circ} \mathrm{C}$ for $10 \mathrm{~min}$, and twice with $0 \cdot 1 \times \mathrm{SSC}, 0 \cdot 1 \% \mathrm{SDS}$, also for $10 \mathrm{~min}$ at $42{ }^{\circ} \mathrm{C}$. To verify loading, control hybridization was performed with a $28 \mathrm{~S}$ DNA probe labeled with $\left[{ }^{32} \mathrm{P}\right] \mathrm{dCTP}$ by random primer. The membranes were exposed at $-80^{\circ} \mathrm{C}$ for $1-4$ days depending on the intensity of the signal obtained. To obtain semiquantitative data for statistical analysis, each gel was run with 5 RNA samples from each experimental group. The density of the each band was normalized with the $28 \mathrm{~S}$ hybridization and expressed as the percentage of the mean of the control group injected with saline.

\section{Statistical analysis}

Data were analyzed using the program STATGRAPHICS plus (Manugistic Inc., Rockville, MD, USA) for Windows. Data are presented as means \pm S.E.M Comparisons between means were made by two-way ANOVA and subsequent Duncan's multiple range test. Significance was assumed at $P<0 \cdot 05$.

\section{Results}

Dexamethasone administration significantly decreased GH receptor mRNA levels in the liver of control rats $(P<0 \cdot 01)$ (Fig. 1A). LPS decreased GH receptor mRNA in salinetreated rats $(P<0 \cdot 01)$ (Fig 1A), but not in dexamethasonepretreated rats (Fig. 1A). In contrast, renal GH receptor mRNA levels were not modified by dexamethasone or by LPS treatment (Fig. 1B).

Similar to the effects found on hepatic GH receptor, dexamethasone administration significantly decreased $(P<0 \cdot 01)$ IGF-I gene expression in the liver of control rats. LPS decreased IGF-I mRNA levels in saline-treated rats $(P<0 \cdot 01)$, but not in dexamethasone-pretreated rats (Fig. 2A). Nevertheless, the effects of dexamethasone and LPS 
injections on the renal IGF-I gene expression are different to the effect found on renal GH receptor (Fig. 2B). Dexamethasone administration did not modify the IGF-I gene expression in the kidney of control rats. LPS significantly decreased $(P<0 \cdot 01)$ the IGF-I mRNA levels in the kidney of saline-treated rats but not in dexamethasonepretreated rats (Fig. 2B).

After administration of LPS, serum concentrations of IGF-I were significantly decreased in saline-treated rats $(P<0 \cdot 01)$ (Fig. 3). Dexamethasone pretreatment did not modify serum concentrations of IGF-I in control rats,

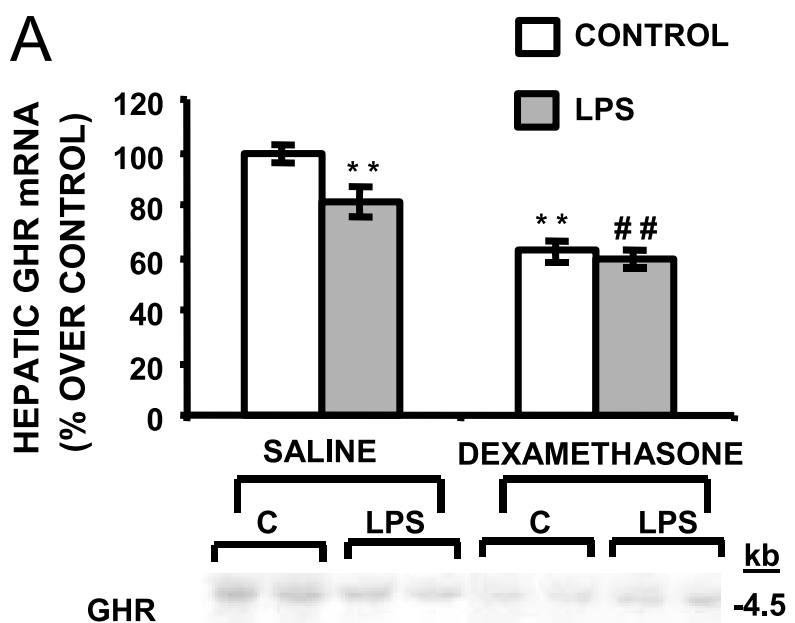

285

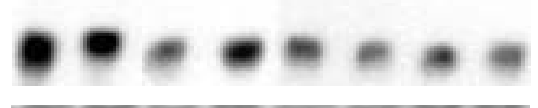

$-1.2$

$\mathrm{B}$

CONTROL
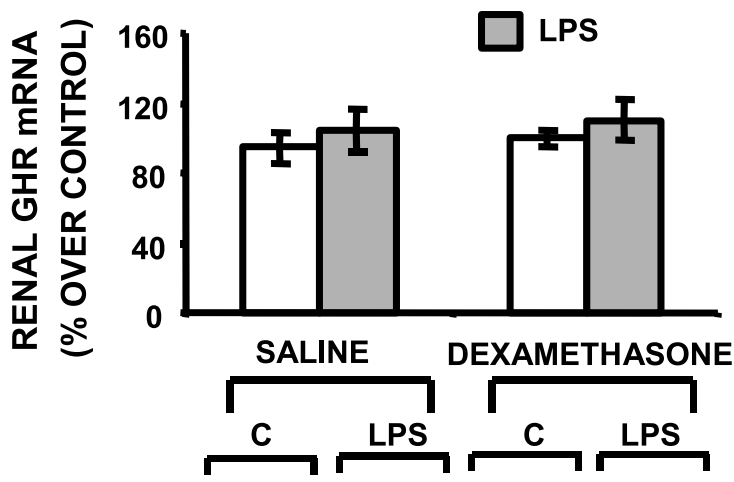

GHR

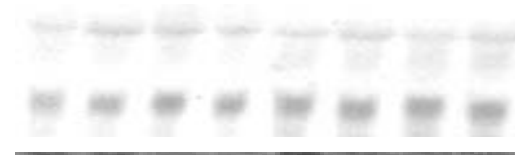

$\underline{k b}$

$-4.5$

$-1.2$

$28 S$

Journal of Endocrinology (2005) 185, 467-476 whereas it clearly attenuated the decrease in serum concentrations of IGF-I caused by LPS injections (Fig. 3).

LPS injections significantly decreased liver IGFBP-3 gene expression $(P<0 \cdot 01)$ (Fig. 4A). Dexamethasone pretreatment increased the IGFBP-3 gene expression in the liver in control rats $(P<0 \cdot 01)$ and attenuated the decrease on IGFBP-3 induced by LPS. Similarly, LPS injections significantly decreased $(P<0.01)$ IGFBP-3 mRNA levels in the kidney (Fig. 4B) and dexamethasone pretreatment prevented this decrease (Fig. 4B).

LPS injections significantly decreased serum concentrations of IGFBP-3 (Fig. 5). Dexamethasone pretreatment increased serum IGFBP-3 concentrations in control rats $(P<0 \cdot 01)$ and attenuated the decrease in serum IGFBP-3 induced by LPS.

IGFBP-3 proteolysis in the serum of rats treated with dexamethasone and LPS is shown in Fig. 6. Proteolysis of IGFBP-3 was not significantly decreased by LPS in saline-treated rats. However, dexamethasone pretreatment clearly decreased the proteolysis of IGFBP-3 in the serum of control rats $(P<0 \cdot 01)$ and decreased LPS-induced IGFBP-3 proteolysis $(P<0 \cdot 01)$ (Fig. 6).

As shown in Fig. 7, in control rats dexamethasone did not modify serum nitrite and nitrate concentrations. LPS increased serum nitrite and nitrate concentrations in saline-treated rats $(P<0 \cdot 01)$, whereas in dexamethasonepretreated rats LPS was not able to increase the nitrite and nitrate levels.

\section{Discussion}

In this study, control and LPS-treated rats were pretreated with dexamethasone to study the effect of glucocorticoid administration on serum IGF-I and IGFBP-3 in the situation of acute inflammation. The results indicate that dexamethasone pretreatment in LPS-treated rats attenuated the decrease in serum IGF-I concentrations by blocking the decrease in its gene expression in the kidney. Moreover, dexamethasone pretreatment in LPS-treated

Figure 1 Hepatic (A) and renal (B) growth hormone receptor (GHR) mRNA expression in rats injected with dexamethasone $(200 \mu \mathrm{g} / \mathrm{kg})$ and lipopolysaccharide (LPS, $250 \mu \mathrm{g} / \mathrm{kg})$. The upper panels show GHR mRNA abundance determined by densitometry and expressed as a percentage of the mean value in control rats treated with saline. Both dexamethasone and LPS decreased GH receptor $m R N A$ in the liver $\left(F_{1,36}=40.91, P<0.001\right.$ and $F_{1,36}=5 \cdot 64$, $P<0.05$ respectively). Data represent the mean \pm S.E.M. for $9-10$ rats per group. ${ }^{* *} P<0.01$ vs control group injected with saline; $\# \# P<0.01$ vs LPS group injected with saline (two-way ANOVA and Duncan's multiple comparison test). The lower panels show a representative Northern blot analysis of GHR mRNA hybridization. RNA was hybridized with an RNA probe for rat GHR mRNA as described in Materials and Methods. The size of the hybridization bands $(\mathrm{kb})$ and ribosomal 28S RNA are indicated on the right; each lane corresponds to an individual animal from the indicated group. C, control. 
rats attenuated the decrease in serum IGFBP-3 by increasing its gene expression in the liver and kidney and by decreasing its serum proteolysis.

As previously reported, LPS injections decreased $\mathrm{GH}$ receptor and IGF-I mRNAs in the liver (Priego et al. 2002a, 2003a). However, in the kidney, LPS did not affect

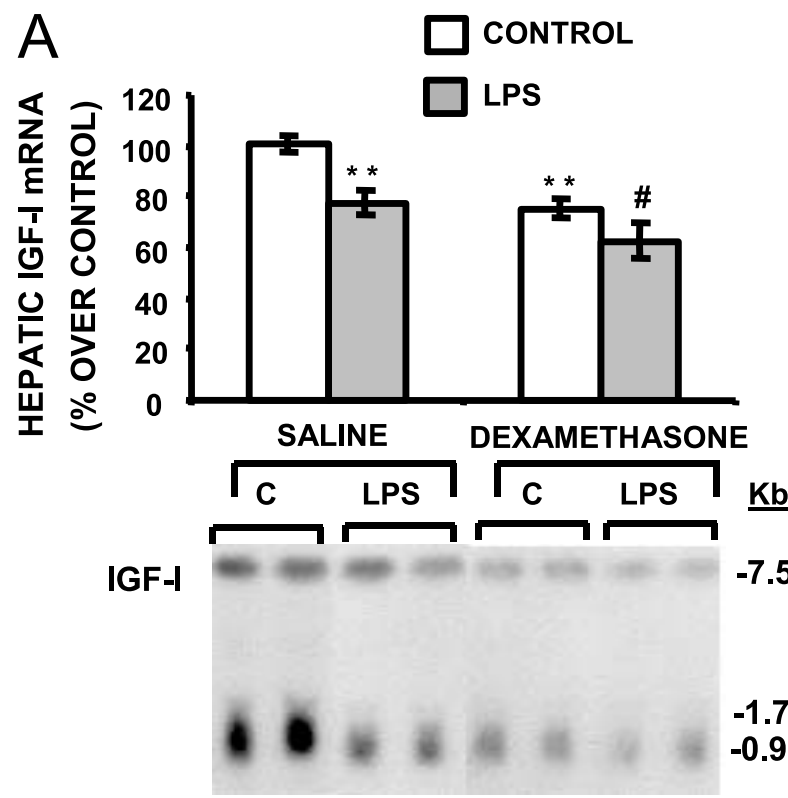

$28 S$

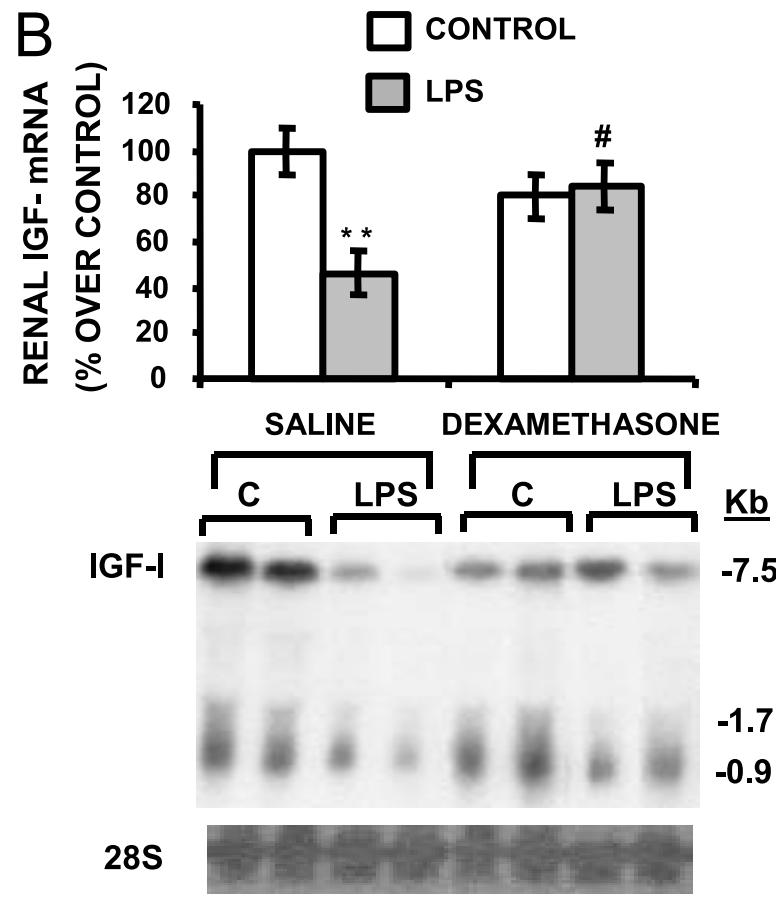

www.endocrinology-journals.org
CONTROL

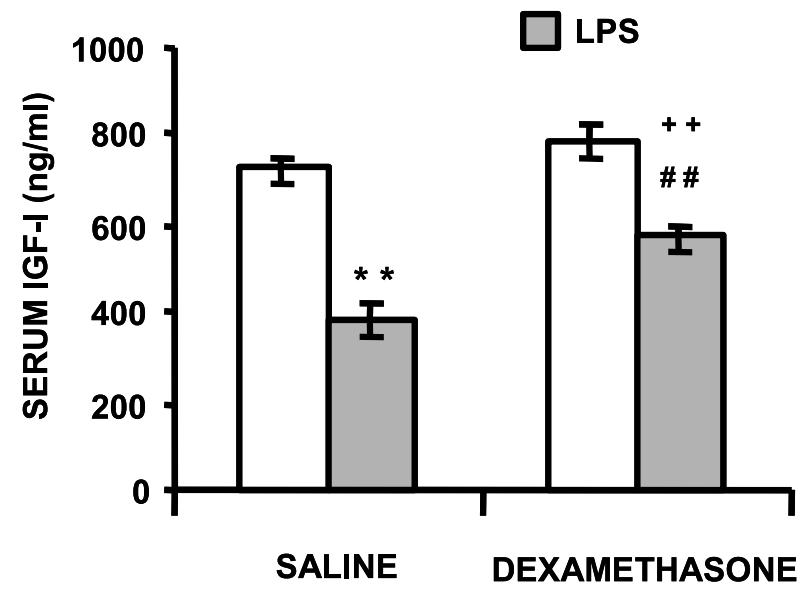

Figure 3 Serum concentrations of insulin-like growth factor (IGF-I) in rats treated with dexamethasone $(200 \mu \mathrm{g} / \mathrm{kg})$ and lipopolysaccharide (LPS, $250 \mu \mathrm{g} / \mathrm{kg}$ ). Dexamethasone pretreatment increased serum IGF-I concentrations $\left(F_{1,35}=14 \cdot 49, P<0 \cdot 001\right)$, whereas LPS decreased the serum concentrations of IGF-I $\left(F_{1,35}=75.55, P<0 \cdot 001\right)$. Each bar represents the mean \pm S.E.M. of $8-10$ rats per group. ${ }^{* *} P<0 \cdot 01$ vs control group injected with saline; $\# \# P<0 \cdot 01$ vs LPS group injected with saline; $++P<0 \cdot 01$ vs control group injected with dexamethasone (two-way ANOVA and Duncan's multiple comparison test).

GH receptor gene expression, although it decreased IGF-I gene expression, as in the liver. These data indicate that, in the kidney, the inhibitory effect of LPS on IGF-I could be mediated by post-receptor GH signaling. We have previously observed that the effects of LPS are stronger on IGF-I than on GH receptor gene expression (Priego et al. 2003a). In fact, with doses of LPS lower than those used in the present study (Priego et al. 2003a) or in arthritic rats (López-Calderón et al. 2001) we found a decrease in hepatic IGF-I mRNA without changes in the GH receptor. Li et al. (1997) reported that LPS increased renal IGF-I mRNA. Discrepancies with our findings could be due to

Figure 2 Hepatic (A) and renal (B) insulin-like growth factor I (IGF-I) gene expression in dexamethasone- $(200 \mu \mathrm{g} / \mathrm{kg})$ and lipopolysaccharide (LPS, $250 \mu \mathrm{g} / \mathrm{kg}$ )-treated rats. Upper panels: liver and kidney IGF-I mRNA expression. Two-way ANOVA revealed that dexamethasone decreased hepatic IGF-I mRNA $\left(F_{1,36}=16 \cdot 63, P<0 \cdot 001\right)$ as did LPS $\left(F_{1,36}=13 \cdot 64, P<0 \cdot 001\right)$. There was an interaction between the effect of dexamethasone and LPS administration on renal IGF-I mRNA $\left(F_{1,35}=5 \cdot 06, P<0 \cdot 05\right)$, as LPS treatment decreased renal IGF-I in saline-pretreated rats but not in dexamethasone-pretreated rats. Data (means \pm S.E.M.) from 5-10 individual rats were quantified by densitometry and expressed as a percentage of the mean value in control rats treated with saline. ${ }^{* *} P<0.01$ vs control group injected with saline; $\# P<0.05$ vs LPS group injected with saline. A representative Northern blot of IGF-I mRNA hybridization is shown in the lower panels of the figure. The size of the hybridization bands $(\mathrm{kb})$ are indicated on the right; each band corresponds to an individual rat from the indicated group. C, control; 28S, $28 \mathrm{~S}$ ribosomal RNA. 
the different form of LPS administration. In the Li et al. study, the analysis was performed $4 \mathrm{~h}$ after a single LPS injection, while we administered two injections of LPS and analyzed the kidney $19 \mathrm{~h}$ after the first injection. In these conditions, we found that LPS decreased IGF-I gene expression in the kidney. Furthermore, in chronic inflammation we also found a decrease in renal IGF-I mRNA (Ibáñez de Cáceres et al. 2002a).

In agreement with previous data (Luo \& Murphy 1989) dexamethasone administration to control rats decreased hepatic IGF-I mRNA. This seems to be due to a direct

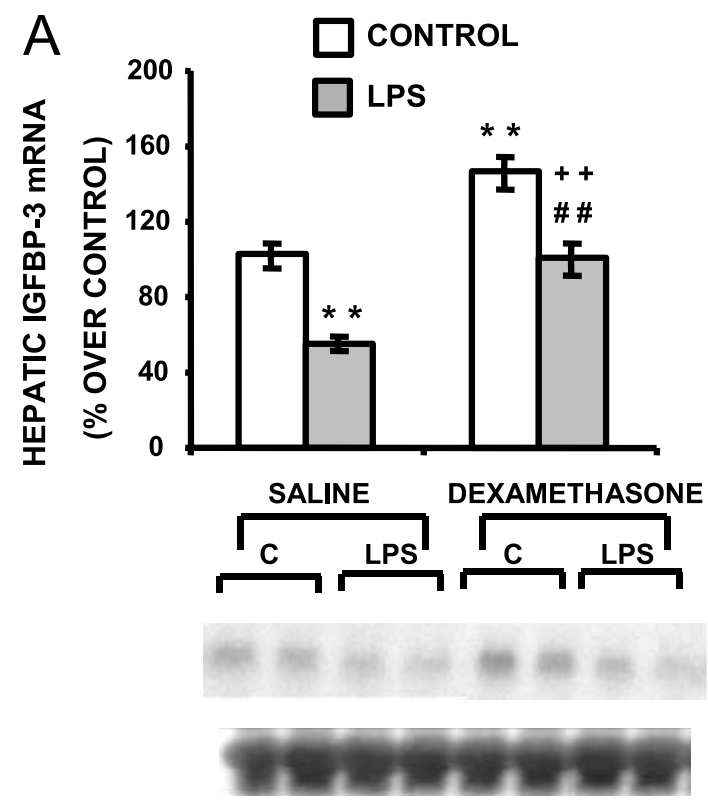

$-2.1 \mathrm{~kb}$
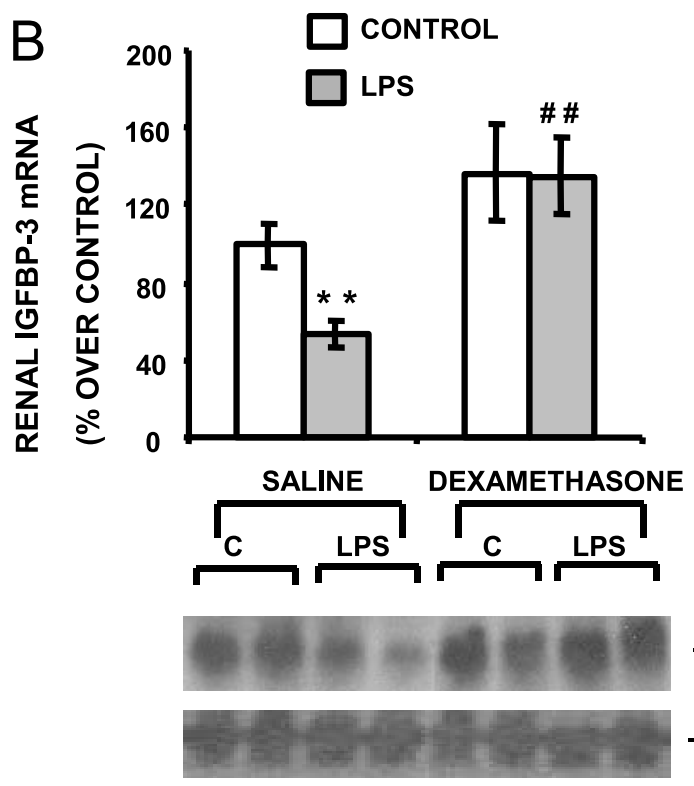

$-2.1 \mathrm{~kb}$

$-28 S$

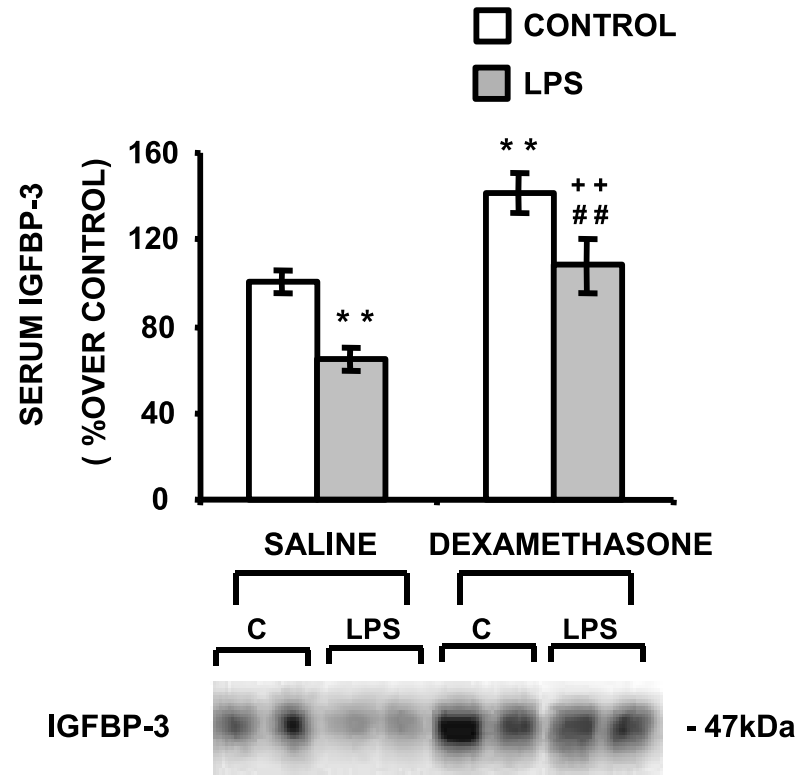

Figure 5 Effect of dexamethasone $(200 \mu \mathrm{g} / \mathrm{kg})$ and lipopolysaccharide (LPS, $250 \mu \mathrm{g} / \mathrm{kg}$ ) administration on the serum IGF-I-binding protein levels of IGFBP-3. IGFBP-3 protein levels were measured by the IGF-I binding activity of the sera. A representative Western ligand blot of IGFBP-3 in $2.5 \mu$ l pools of serum from the different groups is shown in the lower panel. IGFBPs were separated by a $12 \cdot 5 \%$ SDS-PAGE gel, transferred to nitrocellulose, ligand blotted with ${ }^{125}$ I-IGF-I, and visualized via autoradiography; the approximate molecular mass of the band is indicated on the right. In the upper panel, data (means \pm S.E.M.) from 10 individual rats were quantified by densitometry and expressed as a percentage of the mean value of control rats treated with saline. Dexamethasone increased serum concentrations of IGFBP-3 $\left(F_{1,39}=23 \cdot 60, P<0 \cdot 001\right)$, whereas LPS decreased it $\left(\mathrm{F}_{1,39}=16.21, P<0.001\right) .{ }^{*} P<0.01 \mathrm{vs}$ control group injected with saline; $\# \# P<0 \cdot 01$ vs LPS group injected with saline; $++P<0.01$ vs control group injected with dexamethasone (two-way ANOVA and Duncan's multiple comparison test). C, control.

Figure 4 Hepatic (A) and renal (B) IGFBP-3 mRNA content in dexamethasone- $(200 \mu \mathrm{g} / \mathrm{kg})$ and lipopolysaccharide (LPS, $250 \mu \mathrm{g} / \mathrm{kg}$ )-treated rats. A representative Northern blot of IGFBP-3 mRNA hybridization is shown in the lower panels. RNA was hybridized with a cDNA probe for rat IGFBP-3 mRNA as described in Materials and Methods. The size of the hybridization band $(\mathrm{kb})$ and ribosomal 28S RNA are indicated on the right; each lane corresponds to an individual animal from the indicated group. Quantitative analyses are expressed as percentages of data from control rats injected with saline (upper panels). There was no interaction between the effect of dexamethasone and LPS treatment on hepatic and renal IGFBP-3 mRNA. Dexamethasone increased IGFBP-3 mRNA in the liver $\left(F_{1,37}=38.77, P<0.001\right)$ and in the kidney $\left(F_{1,31}=14 \cdot 18, P<0 \cdot 001\right)$, whereas LPS treatment decreased hepatic $\left(F_{1,37}=41.32, P<0.001\right)$ and renal $\left(F_{1,31}=2 \cdot 36\right.$, not significant) IGFBP-3 mRNA. Each bar represents the mean \pm S.E.M. for $5-10$ rats per group. ${ }^{* *} P<0 \cdot 01$ vs control group injected with saline; $\# \# P<0.01$ vs LPS group injected with saline; $++P<0 \cdot 01$ vs control group injected with dexamethasone. C, control. 


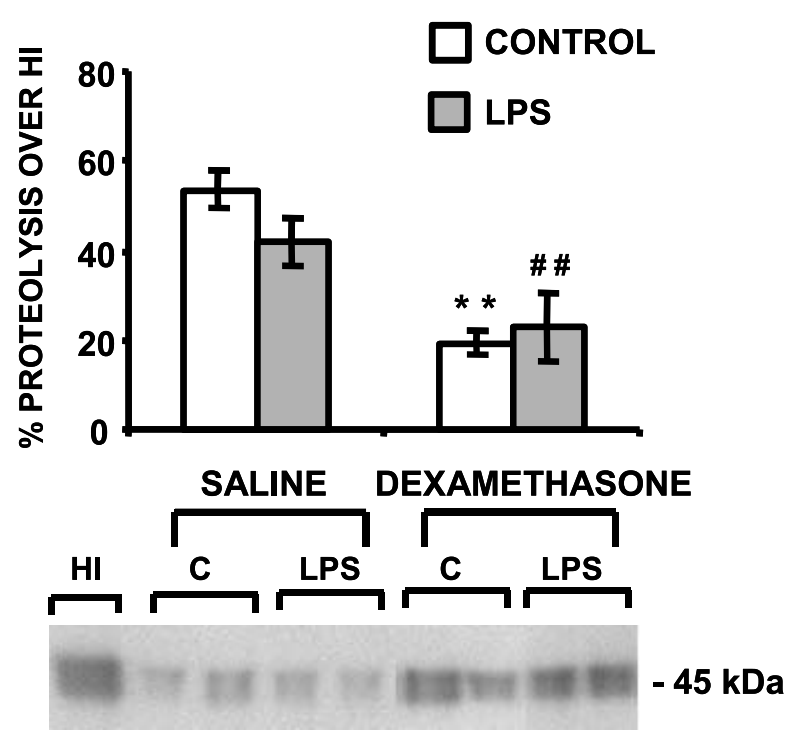

Figure 6 IGFBP-3 proteolysis in serum of dexamethasone$(200 \mu \mathrm{g} / \mathrm{kg})$ and lipopolysaccharide (LPS, $250 \mu \mathrm{g} / \mathrm{kg})$-treated rats.

${ }^{125}$ I- rhIGFBP-3 was incubated for $18 \mathrm{~h}$ at $37^{\circ} \mathrm{C}$ with sera and submitted to SDS-PAGE as described in Materials and Methods. A representative autoradiograph of IGFBP-3 protease assay of rat serum samples from control and experimental groups treated with saline or dexamethasone and heat-inactivated (HI) serum are shown in the lower panel. Heat-inactivated serum was used as a control, as no proteolytic activity is found in the serum after being heated. Molecular mass is shown on the right. IGFBP-3 proteolysis was expressed as a percentage decrease in ${ }^{125}$ I-rhIGFBP-3 in each sample relative to ${ }^{125} \mathrm{I}$-rhIGFBP-3 in control samples incubated with heat-inactivated serum (upper panel). Dexamethasone decreased IGFBP-3 proteolysis $\left(F_{1,35}=22 \cdot 62, P<0 \cdot 001\right)$, whereas LPS treatment did not modify it $\left(F_{1,35}=0.52\right.$, not significant). Each point represents the mean \pm S.E.M. for 9 rats per group. ${ }^{* *} P<0 \cdot 01$ vs control group injected with saline; $\# \# P<0 \cdot 01$ vs LPS group injected with saline (two-way ANOVA and Duncan's multiple comparison test). C, control.

effect of dexamethasone on the liver, since this glucocorticoid decreased hepatic $\mathrm{GH}$ receptor mRNA levels, as described by other authors both in vivo (Gabrielsson et al. 1995, Kritsch et al. 2002) and in vitro (Beauloye et al. 1999). However, we did not find any modifications in GH receptor or IGF-I mRNA levels in the kidney of control rats after dexamethasone administration as previously described by other authors (Luo \& Murphy 1989, Heinrichs et al. 1994). It is possible that the liver is an organ which is more sensitive to the effects of glucocorticoids than is the kidney. In this respect, Luo \& Murphy (1989) reported a decrease in hepatic IGF-I mRNA levels after administering doses of dexamethasone similar to those used in the present study, but only found a decrease in renal IGF-I mRNA with a higher dose.

The LPS-induced decrease in GH receptor and IGF-I mRNAs in the liver was not bigger in rats pretreated with dexamethasone. Furthermore, this glucocorticoid was able to prevent the decrease in renal IGF-I mRNA caused by

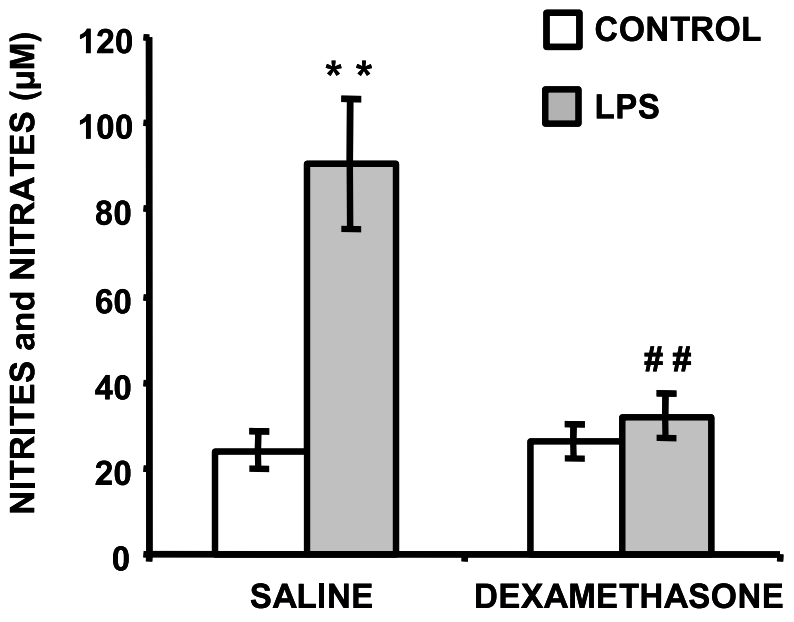

Figure 7 Effect of dexamethasone $(200 \mu \mathrm{g} / \mathrm{kg})$ and lipopolysaccharide (LPS, $250 \mu \mathrm{g} / \mathrm{kg}$ ) injections on serum concentrations of nitrites and nitrates. There was an interaction between the effect of dexamethasone and LPS administration on serum nitrite and nitrate concentrations $\left(F_{1,40}=13 \cdot 38, P<0 \cdot 001\right)$ as LPS increased serum nitrites and nitrates in saline-pretreated rats but not in dexamethasone-pretreated rats. Results are expressed as means \pm S.E.M., $n=10$ rats per group. ${ }^{* *} P<0 \cdot 01 \mathrm{vs}$ control group injected with saline; \#\#P<0.01 vs LPS group injected with saline (two-way ANOVA and Duncan's multiple comparison test).

LPS. These results contrast with others previously reported (Li et al. 1997), in which the LPS-induced decrease in hepatic IGF-I gene expression and the increase in renal IGF-I gene expression were attenuated by pretreatment with the antiglucocorticoid RU-486. However, in this study, the antagonistic action of RU-486 was not effective enough, since it did not increase corticosterone levels in rats treated with LPS. As dexamethasone pretreatment inhibits or does not modify IGF-I mRNAs in the liver and kidney of control rats, but does not modify or prevents the decrease in both organs in LPS-treated rats, our results suggest that dexamethasone pretreatment can inhibit the mechanism by which LPS decreases these two parameters. This mechanism could involve NO, since dexamethasone pretreatment prevents the increase in serum nitrite and nitrate concentrations in LPS-treated rats. Moreover, we have previously reported (Priego et al. 2004) that inhibition of iNOS by aminoguanidine administration prevented the effect of LPS on circulating IGF-I and its gene expression in the liver as well as on circulating nitrite and nitrate concentrations.

There are inconsistent reports of the effect of glucocorticoids on serum IGF-I concentrations, with some studies reporting a reduction in circulating levels (Canalis 1997) and others reporting no effect (Ward et al. 1999). In our study, serum IGF-I was not significantly modified by dexamethasone in control rats, although IGF-I gene expression in the liver was decreased, and it was unchanged in the kidney. Discrepances between serum IGF-I and 
hepatic IGF-I mRNA have previously been described in rats injected with dexamethasone (Luo \& Murphy 1989, Kritsch et al. 2002). According to our results, dexamethasone had little stimulatory effect on serum IGF-I but decreased IGF-I gene expression in the liver (Luo \& Murphy 1989). Dexamethasone pretreatment attenuated the LPS-induced decrease in serum IGF-I in spite of not modifying the decrease in hepatic IGF-I mRNA. The effect of dexamethasone pretreatment on serum IGF-I in LPS-treated rats might, in part, be the result of blocking the decrease in renal IGF-I mRNA. The discordance between serum IGF-I and hepatic IGF-I mRNA in rats that received dexamethasone could also be explained by the fact that glucocorticoids affect production of IGFBPs and thereby may alter the metabolic clearance of IGF-I. Our results are consistent with this hypothesis, since dexamethasone pretreatment increased serum IGFBP-3 in control rats and attenuated the decrease in LPS-treated rats. This increase in serum IGFBP-3 induced by pretreatment with dexamethasone might be contributing, in part, to the increase in serum IGF-I in control and in LPStreated rats, although hepatic IGF-I gene expression was decreased in both groups of rats. In this respect, it has been reported that the steroid, prednisolone, partially normalizes serum IGF-I and IGFBP-3 levels in inflammatory bowel disease (Gronbek et al. 2002).

The increase in serum IGFBP-3 induced by pretreatment with dexamethasone in control and LPS-treated rats is a consequence of the increase in hepatic and renal IGFBP-3 mRNAs. Regulation of IGFBP-3 by dexamethasone has been studied in vitro and in vivo in both adult rats and man. In cocultured hepatic parenchymal and nonparenchymal cells, dexamethasone reduced the production of IGFBP-3 by inhibiting IGFBP-3 gene transcription (Villafuerte et al. 1995). In contrast to this in vitro study, Luo \& Murphy (1990) reported increases in rat serum IGFBP-3 and hepatic IGFBP-3 expression after a single dose of dexamethasone. In humans, Miell et al. (1994) reported an increase in serum IGFBP-3 levels after short-term dexamethasone treatment. Moreover, in Cushing's syndrome increased circulating IGF-I and IGFBP-3 have been reported (Bang et al. 1993). According to our results, dexamethasone also increased IGFBP-3 in organs different from the liver (Koedam et al. 2000). The increase in IGFBP-3 mRNA in liver and kidney caused by dexamethasone pretreatment was higher in LPS-treated than in control rats. This effect might be due, in part, to the inhibitory effects of dexamethasone on $\mathrm{NO}$ production, since dexamethasone decreased the expression of iNOS in hepatocytes (Geller et al. 1993). In addition, in the present study we found that dexamethasone pretreatment blocked the increase in circulating nitrite and nitrate concentrations in LPS-treated rats, and furthermore, we have shown that iNOS inhibition attenuated the inhibitory effect of LPS on hepatic IGFBP-3 mRNA levels (Priego et al. 2004).
To our knowledge, this is the first study in which IGFBP-3 proteolysis was measured in serum of rats treated with dexamethasone. Our findings show that dexamethasone pretreatment decreases IGFBP-3 proteolysis in the serum of control and LPS-treated rats. Dexamethasone can induce a catabolic state and although this state has been characterized by an increased IGFBP-3 proteolysis (Davenport et al. 1992), this does not always occur, as has been observed in arthritic rats (Ibáñez de Cáceres et al. 2002a) and in anorexia nervosa (Stoving et al. 1999). NO has been reported to be involved in the activation of proteolytic enzymes (Trachtman et al. 1996). However, the effects of dexamethasone on serum proteases seems to be independent of $\mathrm{NO}$, since dexamethasone pretreatment decreased IGFBP-3 proteolysis both in control and in LPS-treated rats. Moreover, serum nitrite and nitrate concentrations were only decreased by dexamethasone pretreatment in LPS-treated rats. This hypothesis is supported by our previous studies in LPS-treated rats (Priego et al. 2004) and in experimental arthritis (Ibáñez de Cáceres et al. 2003) after aminoguanidine administration. The inhibition of IGFBP-3 fragmentation occurred concomitantly with the described increase in serum IGFBP-3 in both groups of rats pretreated with dexamethasone. Our findings also show that the increase in hepatic and renal IGFBP-3 gene expression after dexamethasone pretreatment also contributes to the increase in serum IGFBP-3 observed in control and LPS-injected rats.

From the present study, we can conclude that the increase in serum concentrations of IGFBP-3 together with the block of the decrease in renal IGF-I mRNA induced by dexamethasone pretreatment contribute to the attenuation of the inhibitory effect of LPS on serum IGF-I concentrations.

\section{Acknowledgements}

We thank David Sanz for his help in the 28S Northern blot. We are indebted to A Carmona for technical assistance and to C Bickart for the correction of the English in the manuscript. We are grateful to the US National Institute of Diabetes, Digestive and Kidney Diseases, National Hormone and Pituitary Program, for the IGF-I antibody.

\section{Funding}

This work was supported by a grant from Comunidad Autónoma de Madrid (0.870017/2003 1) and a Fellowship from Ministerio de Educación, Cultura y Deporte to T Priego (FPU, AP2001-0053), and to M Granado (FPU, AP2003-2564). The authors declare that there is no conflict of interest that would prejudice the impartiality of this scientific work. 


\section{References}

Albiston AL \& Herington AC 1990 Cloning and characterization of the growth hormone-dependent insulin-like growth factor binding protein (IGFBP-3) in the rat. Biochemical and Biophysical Research Communications 166 892-897.

Annane D, Sebille V, Charpentier C, Bollaert PE, Francois B, Korach JM, Capellier G, Cohen Y, Azoulay E, Troche G, Chaumet-Riffaut P \& Bellissant E 2002 Effect of treatment with low doses of hydrocortisone and fludrocortisone on mortality in patients with septic shock. Journal of the American Medical Association 288 862-871.

Bang P, Degerblad M, Thoren M, Schwander J, Blum W \& Hall K 1993 Insulin-like growth factor (IGF)-I and -II and IGF binding protein (IGFBP)-1, -2 and -3 in serum from patients with Cushing's syndrome. Acta Endocrinologica 128 397-404.

Baumbach WR, Horner DL \& Logan JS 1989 The growth hormonebinding protein in rat serum is an alternatively spliced form of the rat growth hormone receptor. Genes and Development 3 1199-1205.

Beauloye V, Ketelslegers JM, Moreau B \& Thissen JP 1999 Dexamethasone inhibits both growth hormone $(\mathrm{GH})$-induction of insulin-like growth factor-I (IGF-I) mRNA and GH receptor (GHR) mRNA levels in rat primary cultured hepatocytes. Growth Hormone and IGF Research 9 205-211.

Blat C, Villaudy J \& Binoux M 1994 In vivo proteolysis of serum insulin-like growth factor (IGF) binding protein-3 results in increased availability of IGF to target cells. Journal of Clinical Investigation 93 2286-2290.

Canalis E 1997 Insulin-like growth factors and osteoporosis. Bone 21 215-216.

Davenport ML, Isley WL, Pucilowska JB, Pemberton LB, Lyman B, Underwood LE \& Clemmons DR 1992 Insulin-like growth factor-binding protein-3 proteolysis is induced after elective surgery. Journal of Clinical Endocrinology and Metabolism 75 590-595.

De Mellow JSM \& Baxter RC 1988 Growth hormone-dependent insulin-like growth factor (IGF) binding protein both inhibits and potentiates IGF-I-stimulated DNA synthesis in human skin fibroblasts. Biochemical and Biophysical Research Communications 156 199-204.

Fan J, Molina PE, Gelato MC \& Lang CH 1994 Differential tissue regulation of insulin-like growth factor-I content and binding proteins after endotoxin. Endocrinology 134 1685-1692.

Gabrielsson BG, Carmignac DF, Flavell DM \& Robinson ICAF 1995 Steroid regulation of growth hormone $(\mathrm{GH})$ receptor and $\mathrm{GH}$-binding protein messenger ribonucleic acids in the rat. Endocrinology 136 209-217.

Geller DA, Nussler AK, Di Silvio M, Lowenstein CJ, Shapiro RA, Wang SC, Simmons RL \& Billiar TR 1993 Cytokines, endotoxin, and glucocorticoids regulate the expression of inducible nitric oxide synthase in hepatocytes. PNAS 90 522-526.

Gronbek H, Thogersen T, Frystyk J, Vilstrup H, Flyvbjerg A \& Dahlerup JE 2002 Low free and total insulin-like growth factor I (IGF-I) and IGF binding protein-3 levels in chronic inflammatory bowel disease: partial normalization during prednisolone treatment. American Journal of Gastroenterology 97 673-678.

Heinrichs C, Yanovski JA, Roth AH, Yu YM, Domené HM, Yano K, Cutler GB \& Baron J 1994 Dexamethasone increases growth hormone receptor messenger ribonucleic acid levels in liver and growth plate. Endocrinology 135 1113-1118.

Ibáñez de Cáceres I, Holly JMP, Priego T, Martín AI, LópezCalderón A \& Villanúa MA 2002a Arthritis-induced increase in serum levels of IGF-binding protein-3 in rats is secondary to the decrease in its proteolytic activity. Journal of Endocrinology 173 357-364.

Ibáñez de Cáceres I, Priego T, Martín AI, López-Calderón A \& Villanúa MA $2002 b$ GH administration and renal IGF-I system in arthritic rats. Life Sciences 71 139-151.

Ibáñez de Cáceres I, Priego T, Martín AI, Granado M, LópezCalderón A \& Villanúa MA 2003 Effect of inducible nitric oxide synthase inhibition by aminoguanidine on insulin-like growth factor binding protein-3 in adjuvant-induced arthritic rats. European Journal of Pharmacology 481 293-299.

Koedam JA, Hoogerbrugge CM \& Van Buul-Offers SC 2000 Differential regulation of IGF-binding proteins in rabbit costal chondrocytes by IGF-I and dexamethasone. Journal of Endocrinology $165557-567$.

Kritsch KR, Murali S, Adamo ML \& Ney DM 2002 Dexamethasone decreases serum and liver IGF-I and maintains liver IGF-I mRNA in parenterally fed rats. American Journal of Physiology - Regulatory, Integrative and Comparative Physiology 282 R528-R536.

Lamson G, Giudice LC \& Rosenfeld RG 1991 A simple assay for the proteolysis of insulin-like growth factor binding protein-3 (IGFBP-3). Clinical Endocrinology and Metabolism 72 1391-1393.

Lang CH, Pollard V, Fan J, Traber L, Traber DL, Frost RA, Gelato MC \& Prough DS 1997 Acute alterations in growth hormoneinsulin-like growth factor axis in humans injected with endotoxin. American Journal of Physiology - Regulatory, Integrative and Comparative Physiology 273 R371-R378.

Li YH, Fan J \& Lang CH 1997 Differential role of glucocorticoids in mediating endotoxin-induced changes in IGF-I and IGFBP-1. American Journal of Physiology - Regulatory, Integrative and Comparative Physiology 272 R1990-R1997.

López-Calderón A, Ibáñez de Cáceres I, Soto L, Priego T, Martín AI \& Villanúa MA 2001 The decrease in hepatic IGF-I gene expression in arthritic rats is not associated with modifications in hepatic GH receptor mRNA. European Journal of Endocrinology 144 $1-6$.

Luo JM \& Murphy LJ 1989 Dexamethasone inhibits growth hormone induction of insulin-like growth factor-I (IGF-I) messenger ribonucleic acid (mRNA) in hypophysectomized rats and reduces IGF-I mRNA abundance in intact rats. Endocrinology 125 165-171.

Luo JM \& Murphy LJ 1990 Regulation of insulin-like growth factor binding protein-3 expression by dexamethasone. Molecular and Cellular Endocrinology 74 213-219.

Miell JP, Buchanan CR, Norman MR, Maheshwari HG \& Blum WF 1994 The evolution of changes in immunoreactive serum insulin-like growth factors (IGFs), IGF-binding proteins, circulating growth hormone $(\mathrm{GH})$ and $\mathrm{GH}$-binding protein as a result of short-term dexamethasone treatment. Journal of Endocrinology 142 547-554.

Miranda KM, Espey MG \& Wink DA 2001 A rapid, simple spectrophotometric method for simultaneous detection of nitrate and nitrite. Nitric Oxide 5 62-71.

Priego T, Ibáñez de Cáceres I, Martín AI, Villanúa MA \& LópezCalderón A 2002a Glucocorticoids are not necessary for the inhibitory effect of endotoxic shock on serum IGF-I and hepatic IGF-I mRNA. Journal of Endocrinology 172 449-456.

Priego T, Ibáñez de Cáceres I, Martín AI, Villanúa MA \& LópezCalderón A $2002 b$ Hepatic insulin-like growth factor-I binding protein 3 gene expression in rats with endotoxic shock: the role of glucocorticoids. Annals of the New York Academy of Sciences 973 88-90.

Priego T, Granado M, Ibáñez de Cáceres I, Martín AI, Villanúa MA \& López-Calderón A 2003a Endotoxin at low doses stimulates pituitary GH whereas it decreases IGF-I and IGF-binding protein-3 in rats. Journal of Endocrinology 179 107-117.

Priego T, Ibáñez de Cáceres I, Martín AI, Villanúa MA \& LópezCalderón A 2003b Endotoxin decreases serum IGFBP-3 and liver IGFBP-3 mRNA: comparison between Lewis and Wistar rats. Molecular and Cellular Endocrinology 199 23-28.

Priego T, Ibáñez de Cáceres I, Martín AI, Villanúa MA \& LópezCalderón A 2004 NO plays a role in LPS-induced decreases in circulating IGF-I and IGFBP-3 and their gene expression in the liver. American Journal of Physiology - Endocrinology and Metabolism 286 E50-E56.

Roberts CT, Lasky SR, Lowe WL, Seaman WT \& LeRoith D 1987 Molecular cloning of rat insulin-like growth factor I 
complementary deoxyribonucleic acids: differential messenger ribonucleic acid processing and regulation by growth hormone in extra hepatic tissues. Molecular Endocrinology 1 243-248.

Sjogren K, Liu JL, Blad K, Skrtic S, Vidal O, Wallenius V, LeRoith D, Tornell J, Isaksson OG, Jansson JO \& Ohlsson C 1999 Liver-derived insulin-like growth factor I (IGF-I) is the principal source of IGF-I in blood but is not required for postnatal body growth in mice. PNAS 96 7088-7092.

Soto L, Martín AI, Millán S, Vara E \& López-Calderón A 1998 Effects of endotoxin lipopolysaccharide administration on the somatotropic axis. Journal of Endocrinology 159 239-246.

Stoving RK, Flyvbjerg A, Frystyk J, Fisker S, Hangaard J, HasenNord M \& Hagen C 1999 Low serum levels of free and total insulin-like growth factor I (IGF-I) in patients with anorexia nervosa are not associated with increased IGF-binding protein-3 proteolysis. Journal of Clinical Endocrinology and Metabolism $\mathbf{8 4}$ 1346-1350.
Trachtman H, Futterweit S, Garg P, Reddy K \& Singhal PC 1996 Nitric oxide stimulates the activity of a $72-\mathrm{kDa}$ neutral matrix metalloproteinase in cultured rat mesangial cells. Biochemical and Biophysical Research Communications 218 704-708.

Villafuerte BC, Koop BL, Pao CI \& Phillips LS 1995 Glucocorticoid regulation of insulin-like growth factor-binding protein-3. Endocrinology 136 1928-1933.

Ward WE, Atkinson SA, Donovan SM \& Paes B 1999 Bone metabolism and circulating IGF-I and IGFBPs in dexamethasonetreated preterm infants. Early Human Development 56 127-141.

Yildiz O, Doganay M, Aygen B, Guven M, Keleutimur F \& Tutuu A 2002 Physiological-dose steroid therapy in sepsis. Critical Care 6 251-258.

Received in final form 8 March 2005

Accepted 16 March 2005 